\title{
Unravelling the past to manage Newfoundland's forests for the future
}

\author{
by André Arsenault ${ }^{1, *}$, Robert LeBlanc $^{1}$, Eric Earle ${ }^{2}$, Darin Brooks ${ }^{3}$, Bill Clarke ${ }^{4}$, Dan Lavigne ${ }^{2}$ and Lucie Royer ${ }^{5}$
}

\begin{abstract}
The forests of Newfoundland represent a unique type of boreal ecosystem with diverse environmental gradients that exercise strong control over disturbances and vegetation. We have assembled and analyzed a comprehensive database on disturbance history in Newfoundland. Defoliating insects, led by the eastern spruce budworm (Choristoneura fumiferana Clemens) and the hemlock looper (Lambdina fiscellaria Guenée), have the largest disturbance footprint on the island. Infrequent wildfires (fire cycle $=769$ years) had a decisive role in driving forest succession, particularly in the Central Newfoundland Forest and Maritime Barrens ecoregions. We hypothesize that the historical disturbance regime in Newfoundland would not have enabled steady-state conditions, although the amount of old-growth forests and deadwood would likely have been greater than it is today. We argue that the implementation of the natural range of variation (NRV) concept in forest management for such non-equilibrium systems will be challenging in Newfoundland and in other regions of Canada. We propose guiding principles to adapt the NRV concept using ecological knowledge. If a sciencebased approach is desired, assumptions about NRV should be tested using a rigorous experimental design. We encourage the establishment of large-scale experiments in at least a portion of forestry operations to enable an ecosystem sciencebased approach.
\end{abstract}

Keywords: natural disturbance, wildfire, insect defoliation, Newfoundland, ecosystem management, logging, ecological experiments

\section{RÉSUMÉ}

Les forêts de Terre-Neuve constituent un type particulier décosystème boréal qui présente divers gradients écologiques qui ont une influence marquée sur les perturbations et la végétation. Nous avons assemblé et analysé une base de données exhaustive sur l'historique des perturbations à Terre-Neuve. Les insectes défoliateurs, principalement la tordeuse des bourgeons de lépinette (Choristoneura fumiferana Clemens) et l'arpenteuse de la pruche (Lambdina fiscellaria Guenée), sont ceux qui ont occasionné les plus fortes perturbations sur l'île. Les rares feux de forêt (cycle des feux $=769$ ans) ont joué un rôle moteur dans la succession des peuplements forestiers, notamment dans les écorégions de la forêt du centre de Terre-Neuve et de la toundra des Maritimes. Nous posons l'hypothèse que le régime historique des perturbations de Terre-Neuve n'aurait pas permis d'atteindre des conditions stables, même s'il était possible d’avoir plus de vieilles forêts et de bois mort que présentement. Nous soutenons qu'il sera très difficile d’appliquer le concept de plage de variabilité naturelle $(\mathrm{PVN})$ en aménagement forestier pour de tels systèmes non équilibrés à Terre-Neuve et dans d’autres régions du Canada. Nous proposons des principes directeurs pour adapter le concept de PVN à partir des connaissances écologiques. Pour adopter une saine approche scientifique, il faut vérifier les hypothèses sur la PVN avec une méthodologie expérimentale rigoureuse. Nous suggérons la mise en place d’essais à grande échelle dans au moins une portion des forêts exploitées afin de permettre une approche écosystémique fondée sur des bases scientifiques.

Mots clés : perturbation naturelle, feux de forêts, défoliation par les insectes, Terre-Neuve, aménagement écosystémique, exploitation forestière, essais écologiques

\section{Introduction}

The forests of Newfoundland represent a unique type of boreal ecosystem at the edge of North America, situated on a large island surrounded by the Gulf of St. Lawrence, the Atlantic Ocean, the Labrador Sea, and the Strait of Belle Isle, and thus subject to exceptional oceanic and continental influences. They are also distributed along ecological gradients of latitude (lower, mid, and northern boreal), elevation, continentality, substrate chemistry, and hydrology (Damman 1983). These gradients exert strong influences on natural disturbances and vegetation. In recent years, a trend toward ecosystem management (Grumbine 1994) and interests to secure market access under pressure from environmental groups (Rametsteinera and Simula 2003) have created a need

\footnotetext{
${ }_{1}^{1}$ Natural Resources Canada, Canadian Forest Service - Atlantic Forestry Centre, Corner Brook, NL; ${ }^{\star}$ Corresponding author’s email: andre.arsenault2@canada.ca.

${ }^{2}$ Forest Service of Newfoundland and Labrador, Department of Fisheries, Forestry and Agrifoods

${ }^{3}$ College of the North Atlantic, Corner Brook, NL

${ }^{4}$ Forest Service of Newfoundland and Labrador, Department of Fisheries, Forestry and Agrifoods, Ecology Centre, Mount Pearl, NL

${ }^{5}$ Natural Resources Canada, Canadian Forest Service - Laurentian Forestry Centre, Sainte-Foy, Quebec
} 
for extensive information on natural disturbances and how they influence the dynamics and ecology of forests. In Newfoundland and Labrador, the provincial forest management strategy (Newfoundland and Labrador Department of Natural Resources 2014) and forest certification initiatives like the Forest Stewardship Council (FSC Canada 2015) and the Canadian Boreal Forest Agreement (CBFA 2015) all require the best available information on natural disturbances to help guide sustainable forest management.

\section{Why is knowledge on natural disturbances important?}

Natural disturbances represent significant ecological processes in forest landscapes, and their historical spatial and temporal patterns can provide pertinent information affecting the human footprint and forest biodiversity in managed forests. For example, a good understanding of historical patterns and effects of natural disturbances can provide some guidance for conservation biology issues such as the relative amount of old-growth forests in landscapes (Lesica 1996), bench-mark size for protected areas (Leroux et al. 2007), and the type of forest structure that is considered "natural" without human interferences such as fire suppression or clear cutting (Foster et al. 1996). The key assumption is that, if forest management and planning activities operate within a similar range of variation as to those under which species evolved, the risk of affecting forest organisms negatively should be limited. Like most assumptions, this one needs to be tested using robust experimental approaches such as large-scale experiments and rigorous critical thinking.

Another useful aspect of developing rigorous knowledge of historical disturbances is the potential to integrate anticipated disturbances into forest management and planning to reduce risk to life, property, and natural resources. The development of the Canadian Forest Fire Behavior Prediction System is a well-known example of using knowledge on historical wildfire patterns and clever experiments to anticipate and mitigate wildfire risk (Van Wagner 1965, 1971a; Forestry Canada Fire Danger Group 1992). Other examples include the development of applications for assessing risk of landslides after wildfire (Jordan et al. 2006, Robichaud and Ashmun 2012) and assessing risk of avalanches in managed forests (Weir 2002). Forest planning to achieve specific targets, such as the amount of forest in late seral stages, annual allowable cut, and many other objectives, can be improved by considering information on natural disturbances (Klenner et al. 1999, Acuna et al. 2010).

Pros and cons of applying natural disturbance information in land-use planning

It is very appealing to use natural disturbances to provide "natural" reference conditions to help guide strategic planning in managed landscapes. However, there are a number of challenges that need to be acknowledged that relate to the definition of naturalness (Sprugel 1991) and to the fact that most ecosystems operate in non-equilibrium conditions (Botkin 1990). A considerable challenge is the uncertainty associated with historical information and how scientists and forestry professionals deal with this uncertainty and differences in interpretation. Diversity in opinion over historical disturbance patterns has generated a number of vigorous scientific debates over a wide range of ecosystems that often have sig- nificant implications for society, including investments of millions of public dollars into activities on the land aimed at fixing a perceived problem, and potential loss of habitats and other values associated with these initiatives. Some examples of these debates have occurred over the management of coastal temperate rainforests in British Columbia (Arsenault 1995), dry forest ecosystems of western North America (Klenner et al. 2008), effectiveness of fire suppression in the boreal forest of Canada (Martell 1996), and post-wildfire management (Donato et al. 2006). These controversies create a problem and an opportunity for advancing science and its applications. The problem is that these debates can generate a situation that perpetuates thinking based on the strength of the belief rather than on the strength of the evidence. On a more positive note, the opportunity is that scientists and foresters from both sides of an argument have the ability to examine differences in interpretation together in order to identify more precisely the uncertainties leading to welldefined research questions and the development of testable hypotheses (see Kaufmann et al. 2007 for an inspiring example of this). This practice can lead to an adaptive management approach that allows scientists and managers to implement corrective actions and learn by monitoring indicators of ecosystem integrity and experimenting with the study system (Lindenmayer and Likens 2009, Arsenault and Larocque 2016).

\section{Disturbances in the boreal forest, with a focus on the island of Newfoundland}

Our understanding of the role of natural disturbances in the boreal forest biome has evolved from a rather simplistic paradigm where large catastrophic fires produced predominantly young forest landscapes, to a more complex paradigm involving multiple disturbances interacting with each other and with climate, producing an equally complex landscape composed of a mosaic of stand ages and forest structure (Bergeron and Fenton 2012). These paradigms are not completely mutually exclusive, and parts of both may apply together or individually depending on scale and geography. Thus, it is important to anchor knowledge of natural disturbance history with strong regional and local information. There are some papers on localized disturbance history and forest dynamics for parts of Newfoundland (McCarthy and Weetman 2006, 2007), and several reports provide valuable information (Wilton and Evans 1974, Otvos et al. 1979, Blais et al. 1981, van Nostrand et al. 1981, Simpson and Coy 1999, Brown and Wells 2011 ${ }^{1}$ ) and have initiated a good synthesis. In this paper, we provide a comprehensive review of what we know about the natural disturbance regime of Newfoundland's forest landscapes using the literature and available data sources. We also examine the management implications of this information with a critical assessment of the application of the natural range of variation (NRV) concept for non-equilibrium systems.

\footnotetext{
${ }^{1}$ Brown, W.A. and E.D. Wells. 2011. The pre-industrial condition of the forest limits of Corner Brook Pulp and Paper Limited. Unpublished report prepared by Corner Brook Pulp and Paper Ltd to address the requirements of the Forest Stewardship Council, National Boreal Standard.
} 


\section{Study area}

The island of Newfoundland is $111390 \mathrm{~km}^{2}$, represents $27 \%$ of the land base of the province of Newfoundland and Labrador, and is the $15^{\text {th }}$ largest island in the world. All of its forests are within the boreal shield ecozone and are largely dominated by balsam fir (Abies balsamea (L.) Mill.) and black spruce (Picea mariana (Mill.) B.S.P.). Other important conifers include white spruce (Picea glauca (Moench) Voss) and eastern larch (Larix laricina (Du Roi) K. Koch), referred to locally as juniper. Eastern white pine (Pinus strobus L.) is thought to have been much more abundant in the past, but logging and the introduction of the white pine blister rust (Cronartium ribicola J.C. Fisch.) may have significantly reduced its occurrence and regeneration (Meades 2008). Red pine (Pinus resinosa Ait.) has a much more localized distribution, associated with drier ecosites in central Newfoundland as far east as the Terra Nova area. Both pine species are considered species of conservation concern. Fourteen species of native broadleaf trees occur on the island, including white birch (Betula papyrifera Marsh.), yellow birch (Betula alleghaniensis Britt.), mountain birch (Betula cordifolia Regel), balsam poplar (Populus balsamifera L.), red maple (Acer rubrum L.), trembling aspen (Populus tremuloides Michx.), American mountain ash (Sorbus americana Marsh.), showy mountain ash (Sorbus decora (Sarg.) C.K. Schneid.), black ash (Fraxinus nigra Marsh.), and a number of smaller tree species, including speckled alder (Alnus incana ssp. rugosa (Du Roi) J. Clausen), mountain alder (Alnus incana ssp. tenuifolia (Nutt.) Breit.), pin cherry (Prunus pensylvanica L.f.), choke cherry (Prunus virginiana L.), and mountain maple (Acer spicatum Lamb.).

Although Newfoundland belongs to the boreal forest biome, it is unique in part due to a combination of geological, continental, and oceanic influences creating a semi-coastal environment with an average annual temperature of $5^{\circ} \mathrm{C}$ and $1400 \mathrm{~mm}$ of annual precipitation. The temperature becomes increasingly colder from south to north, and the amount of precipitation tends to be highest on the south and east coasts and the Great Northern Peninsula, and least in Central Newfoundland, but the mountain ranges and the numerous inlets and peninsulas influence local climatic conditions.

Newfoundland can be divided into nine distinct ecoregions (Fig. 1) based on the relationship between vegetation, the surrounding landscape, and environmental gradients, ultimately affecting the occurrence, type, and severity of natural disturbances in those ecoregions (Damman 1983, Meades and Moores 1994).

\section{Methods}

We used a combination of published reports and papers as well as available data from Natural Resources Canada and the Forest Service of Newfoundland and Labrador, Department of Fisheries, Forestry and Agrifoods to get a comprehensive picture of disturbance regimes in Newfoundland. We focused mainly on forest harvesting, wildfire, insect defoliation, and windthrow. In order to analyze the biogeographical aspect of natural disturbances, we used the ecoregion framework (Damman 1983) that related environmental variables with landscape characteristics. Vegetation toposequence and structure, and floristic composition and distribution were the primary criteria used to subdivide insular Newfoundland into major climatic subdivisions, or ecoregions.

\section{Data sources}

Digital harvesting records spanning 1926-2012 were compiled by the Forest Service of Newfoundland and Labrador, Department of Fisheries, Forestry and Agrifoods. Currently this is the most accurate and up-to-date harvesting data set for the Island and is mainly composed of historical Bowater and Abitibi records. This data set contained the year of harvest, and using a GIS, we calculated the area of each harvesting polygon. Due to inaccuracies from using multiple methods to compile the data (digitizing old paper records, using fixed-wing aircraft to trace harvested areas), there was a slight spatial shift of approximately $200 \mathrm{~m}$ to the northeast. This was a relatively minor issue in this study, as we were only interested in the extent of the harvesting within each ecoregion and throughout Newfoundland as a whole. For the Avalon Forest ecoregion, this exercise was complemented by examining old reports and using personal knowledge of co-author Bill Clarke.

Wildfire information was obtained from several data sources, the first being from a Natural Resources Canada information report (Wilton and Evans 1974) describing fire events in Newfoundland from 1619-1960, some of which included fire size. Most of the fire events had a general location (i.e., city or town), and lat./long. coordinates were gathered for these using Google Maps for the purpose of importing into a GIS. Individual fire events from the report were transcribed into a database. The original data sources for the compilation by Wilton and Evans (1974) were from varied sources but most importantly from newspaper stories. This is obviously not a perfect situation as there is a bias toward where people are to witness these events. A similar limitation exists with the early years of the large wildfire database described next.

The second data source was from a large 200 ha fire database (Stocks et al. 2002) compiled by the Canadian Forest Service from 1959-2010 and augmented to 2013 from the third data source (wildfire data compiled by the Forest Service of Newfoundland and Labrador, Department of Fisheries, Forestry and Agrifoods). The latter two data sets contained year, size, cause, and location. We then combined all three fire data sets into one spatially explicit database to assess the geographical pattern of wildfire and to make summaries by ecoregion. Fire points were buffered to create an area equal to the actual fire size on record so that we could visually inspect the extent of wildfire disturbance. The fire map only indicates the quantitative area of the fire and not the actual physical boundaries of the area affected. The annual reports of the Newfoundland and Labrador Forest Protection Association, and Fig. 2 of Wilton and Evans (1974), were also consulted and helped fill some data missing in the other sources.

Digital files of annual aerial surveys of eastern spruce budworm (Choristoneura fumiferana Clem.; ESB) and hemlock looper (Lambdina fiscellaria Guenée; HL) defoliation, as part of the Forest Insect and Disease Survey (FIDS) program conducted by Natural Resources Canada (Sterner and Davidson 1981), were compiled and used for analysis. The defoliation data covered 1972 to 1992 for the ESB, and 1966 to 1998 for the HL. The ESB defoliation data were augmented from 1949-1968 (Hardy et al. 1986), but no information on defoliation severity was available in this data set and was only included in part of our analysis looking at the total area defo- 


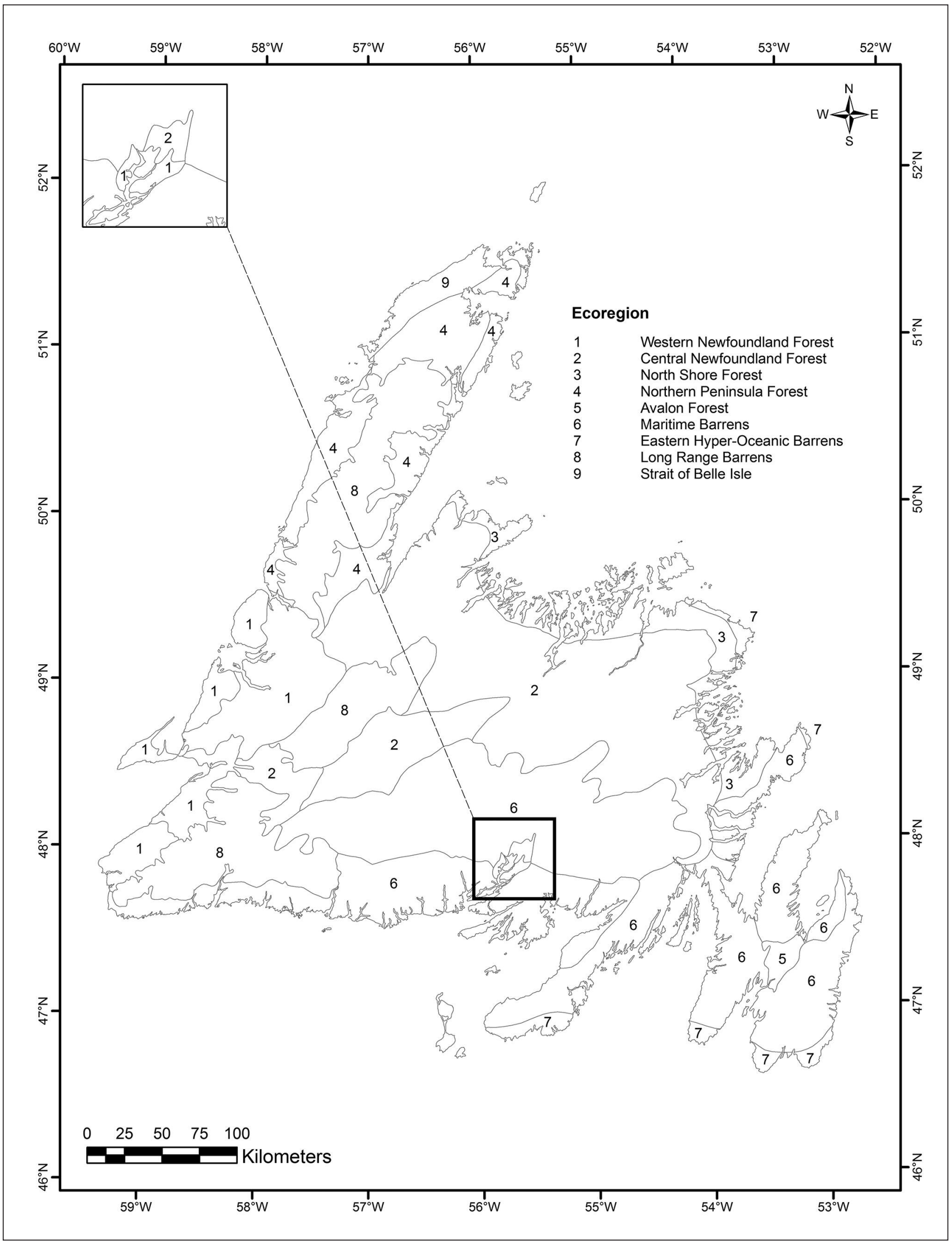

Fig. 1. The ecoregions of Newfoundland after Damman (1983) and Meades and Moores (1994). Source of data: Department of Environment and Conservation, Newfoundland and Labrador. 


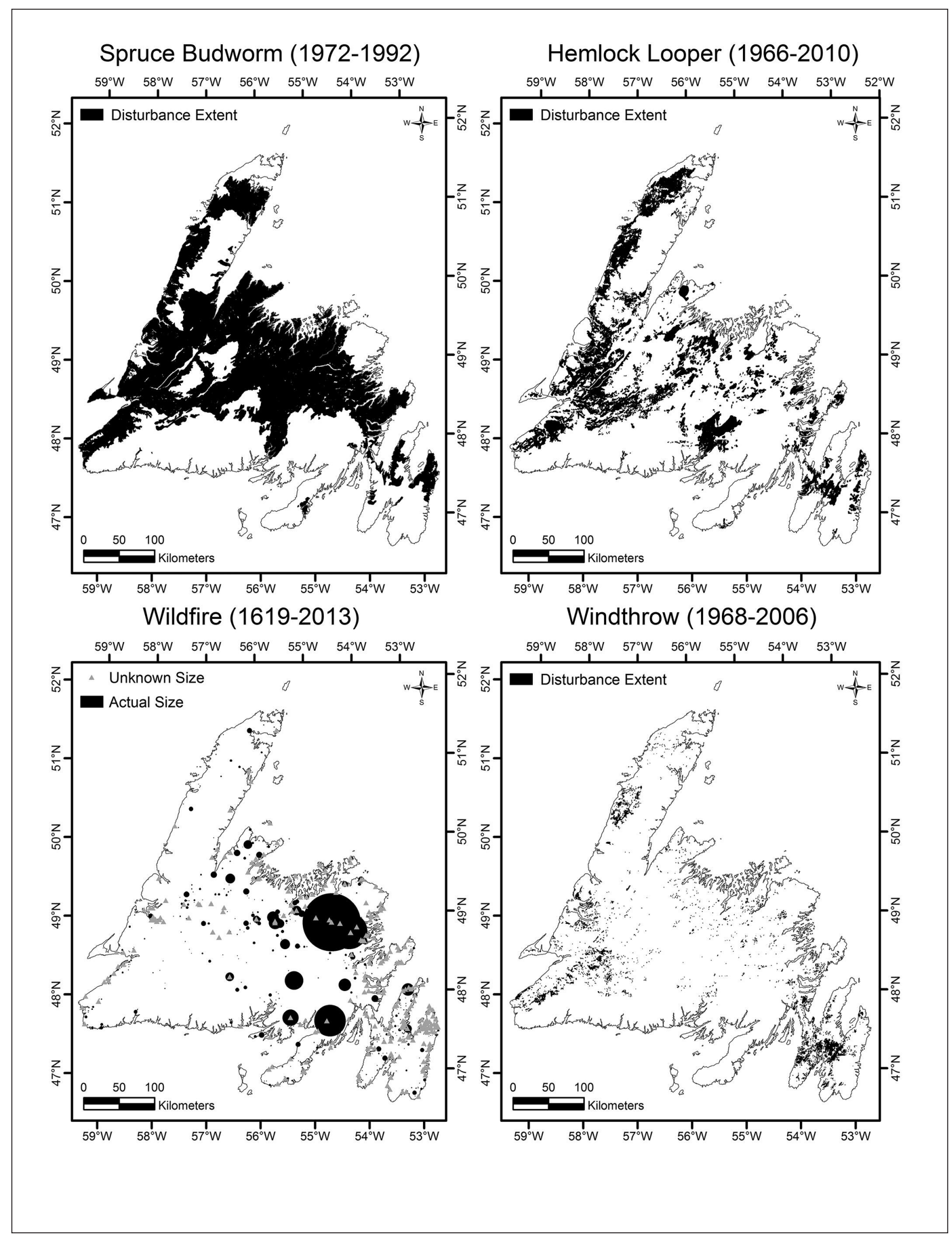

Fig. 2. The spatial distribution and extent of major disturbances. Note: the map in the wildfire panel depicts the location and size of wildfire events. Small fires will go unnoticed on this map, and readers should look at Fig. 3a to see the locations of all wildfire events. 
liated, regardless of defoliation severity. The HL defoliation data were augmented to 2010 by surveys conducted by the Forest Service of Newfoundland and Labrador, Department of Fisheries, Forestry and Agrifoods, and by information contained in Otvos et al. (1979). Information on the temporal pattern of tree mortality associated with ESB and HL were obtained from Otvos et al. (1979) and Armstrong and Ives (1995). We also had records for the balsam fir sawfly (Neodiprion abietis Harris), the yellow headed spruce sawfly (Pikonema alaskensis Rohwer), the rusty tussock moth (Orgyia antiqua L.), and the spruce bud moth (Zeiraphera canadensis Mut. \& Free.), but the timespan of data coverage (Table 1) was relatively limited when compared with the ESB and the HL. Due to unavoidable inaccuracies during aerial surveys (in-flight estimation of defoliation, tracing onto paper maps, and then digitizing defoliation polygons), portions of insect defoliation polygons overlapped with water bodies and non-forested areas (bogs, rock barrens). The areas of overlap were excluded from our analyses so that only forested areas were examined.

Windthrow polygons were digitized from aerial photography and compiled by the Forest Service of Newfoundland and Labrador, Department of Fisheries, Forestry and Agrifoods. Windthrow data covered the timespan from 1968-2006. Again, due to inaccuracies during the mapping process, portions of the windthrow polygons overlapped with water bodies. As with the insect defoliation data sets, we excluded the overlapping areas, and only forested areas were examined.

Using a GIS, all disturbances were summarized by year and by ecoregion. The area affected (footprint only, to remove any overlap between years) per ecoregion was calculated (with the exception of fire) to better quantify the geographical extent of the disturbances. Due to the uncertainty around the physical boundaries of our fire data (records consisted of geographical coordinates), we were unable to delineate areas of overlap between fires and were constrained to report the full extent of fire disturbance, rather than the footprint of the area affected. Although this synthesis of disturbance data is the most comprehensive to date for Newfoundland, it does have certain limitations. We are confident that the spatial and temporal patterns described are accurate, however an important limitation is that the absence of a specific disturbance in a certain place at a certain time cannot be guaranteed without using other research approaches in the field such as paleoecology and dendrochronology. This problem becomes increasingly important the further back in time we infer patterns from our records and hence requires some caution during the interpretation of our results.

\section{Results and Discussion \\ Disturbance types: Synopsis}

The dominant abiotic disturbance agents include wildfire (Wilton and Evans 1974), strong windstorms (Glode 2009), and floods, landslides, and avalanches (Batterson et al. 1995, Liverman et al. 2000). Biotic agents include defoliating insects such as the ESB and HL, bark beetles such as the spruce bark beetle (Ips typographus L.), and pathogenic fungi such as Armillaria root disease. The dominant anthropogenic disturbances include forest harvesting, mining, mining exploration, air pollution, human-caused fires, and introduced species. The introduction of exotic species on the island of Newfoundland has had some significant effects on ecosystems. Examples include the introduction of the moose (Alces alces L.; Ralph 1967, Bergerud and Manuel 1968, Thompson and Curran 1992), squirrel (Tamiasciurus hudsonicus Erxleben; Payne 1976), balsam woolly adelgid (Adelges piceae Ratz.; Balch and Carroll 1958, Carroll and Bryant 1960, Quiring et al. 2008), and white pine blister rust which have significantly affected the vigour and dynamics of certain forest types. Although the boreal forest is often synonymous with wildfire (Payette 1992), the natural disturbance footprint is most commonly driven by defoliating insects in Newfoundland, led by the ESB and the HL (Fig. 2). Fire and windthrow also occur throughout Newfoundland, but they are more frequent in certain ecoregions, reflecting specific biophysical properties.

\section{Harvesting}

The majority of forest harvesting has been done in the Central (0.67 million ha) and Western (0.26 million ha) Newfoundland Forest ecoregions, which together make up $78 \%$ of the harvesting footprint for the island (Table 2). The Central Newfoundland Forest ecoregion is the largest in area and at one point had a pulp and paper mill and a large number of saw mills operating in the area; the Western Newfoundland Forest ecoregion still has a pulp and paper mill operating today, so it is no surprise that harvesting in these two ecoregions makes up the majority of the historical harvesting disturbance for the island. It was not until 1890 that Newfoundland entered the export lumber market, but sawmills existed long before that, although records pertaining to them are both rare and

Table 1. Minimum, mean, maximum, and standard deviation (SD) of historical disturbance events for the island of Newfoundland. All numbers are given in hectares

\begin{tabular}{lcrrrr}
\hline Disturbance & Timeline & Min. & Mean & Max. & SD \\
\hline Harvesting & $1926-2012$ & $<0.00$ & 11.60 & 18478.38 & 99.43 \\
Wildfire & $1619-2013$ & 0.01 & 376.44 & 517998.10 & 9522.64 \\
Windthrow & $1968-2006$ & $<0.00$ & 3.90 & 295.61 & 9.72 \\
Spruce budworm & $1972-1992$ & $<0.00$ & 97.07 & 119801.24 & 1257.58 \\
Hemlock looper & $1966-2010$ & $<0.00$ & 25.95 & 14212.91 & 154.21 \\
Balsam fir sawfly & $1997-2010$ & $<0.00$ & 153.73 & 39391.79 & 1435.96 \\
Yellow headed spruce sawfly & $1999-2008$ & $<0.00$ & 39.70 & 916.14 & 118.56 \\
Rusty tussock moth & 2000 & 0.67 & 64.02 & 628.43 & 158.84 \\
Spruce bud moth & $2005-2007$ & 0.01 & 17.48 & 178.15 & 33.83 \\
\hline
\end{tabular}


Table 2. Disturbance footprints (\% of ecoregion area) within each of the ecoregions; total footprint (ha) for each disturbance is in bold at the bottom of the table. Timelines for each disturbance are provided in Table 1.

\begin{tabular}{|c|c|c|c|c|c|c|c|c|c|c|}
\hline Ecoregion & $\begin{array}{l}\text { Eco- } \\
\text { region } \\
\text { Area } \\
\text { (ha) }\end{array}$ & $\begin{array}{l}\text { Harvest- } \\
\text { ing }\end{array}$ & $\begin{array}{l}\text { Wild- } \\
\text { fire }\end{array}$ & $\begin{array}{l}\text { Wind- } \\
\text { throw }\end{array}$ & $\begin{array}{l}\text { Spruce } \\
\text { Bud- } \\
\text { worm }\end{array}$ & $\begin{array}{l}\text { Hem- } \\
\text { lock } \\
\text { Looper }\end{array}$ & $\begin{array}{c}\text { Balsam } \\
\text { Fir } \\
\text { Sawfly }\end{array}$ & $\begin{array}{l}\text { Yellow } \\
\text { Headed } \\
\text { Spruce } \\
\text { Sawfly }\end{array}$ & $\begin{array}{l}\text { Rusty } \\
\text { Tussock } \\
\text { Moth }\end{array}$ & $\begin{array}{c}\text { Spruce } \\
\text { Bud } \\
\text { Moth }\end{array}$ \\
\hline Avalon Forest & 55565 & 45.0 & 1.1 & 7.1 & 9.9 & 38.1 & 0.0 & 0.0 & 0.0 & 0.0 \\
\hline $\begin{array}{l}\text { Central Newfound- } \\
\text { land Forest }\end{array}$ & 2871525 & 23.3 & 33.9 & 0.3 & 65.9 & 14.1 & 1.6 & 0.1 & 0.0 & 0.0 \\
\hline $\begin{array}{l}\text { Eastern Hyper- } \\
\text { Oceanic Barrens }\end{array}$ & 160343 & 0.5 & 6.2 & $<0.0$ & 0.0 & 1.5 & 2.4 & 0.0 & 0.0 & 0.0 \\
\hline Long Range Barrens & 1657762 & 1.5 & 0.3 & 0.5 & 16.1 & 5.9 & 0.7 & $<0.0$ & 0.0 & 0.0 \\
\hline Maritime Barrens & 3790141 & 1.2 & 9.9 & 0.3 & 12.7 & 5.9 & 0.2 & $<0.0$ & 0.0 & 0.0 \\
\hline North Shore Forest & 550615 & 13.1 & 3.8 & 0.1 & 49.6 & 4.0 & 0.0 & 0.0 & 0.0 & 0.0 \\
\hline $\begin{array}{l}\text { Northern Peninsula } \\
\text { Forest }\end{array}$ & 854289 & 12.8 & 0.6 & 0.5 & 55.4 & 21.7 & 0.1 & $<0.0$ & 0.1 & 0.1 \\
\hline Strait of Belle Isle & 188808 & 1.5 & 1.8 & $<0.0$ & 6.1 & 14.4 & 0.0 & 0.0 & 0.0 & 0.0 \\
\hline $\begin{array}{l}\text { Western Newfound- } \\
\text { land Forest }\end{array}$ & 993493 & 25.9 & 1.1 & 0.8 & 69.0 & 32.3 & 25.2 & 0.0 & 0.0 & 0.0 \\
\hline Total & 11122540 & 1207759 & 1404120 & 44167 & 4090417 & 1304281 & 319107 & 3242 & 896 & 528 \\
\hline
\end{tabular}

${ }^{*}$ Due to the uncertainty of the physical boundaries of our fire data, it was not possible to delineate areas of overlap; the summaries for wildfire in Table 2 are the full extent of the disturbance.

obscure. In 1905, six large sawmills were in operation producing between $20000 \mathrm{fbm}$ (foot, board measure) per day at the Fisher's mill to $300000 \mathrm{fbm}$ per day at the Newfoundland Timber Estates Limited (Thoms 1967). In the 1930s, there were over 600 mills drawing on the forests of Newfoundland for raw material for the manufacture of building lumber, package and cooperage stock, and miscellaneous timber products, as well as one plant manufacturing birch veneer (Turner 1937). From 1942 to 1957, between 1300 and 1600 sawmills reported sawing consistently between 40000000 and $69000000 \mathrm{fbm}$ per year (Thoms 1967). Between 1898 and 1992, an estimated 3757000 cords of export wood (pitprops and round pulpwood) were shipped from Newfoundland and Labrador. Of this, about 7\% came from Labrador and 93\% from the island of Newfoundland. Export wood was shipped from 19 different locations on the northeast coast (Chance Harbour to Botwood), 16 locations on the north central coast (Tommy's Arm to Sop's Arm), and nine locations on the Great Northern Peninsula, as well as from Port aux Port, St. George's, Bay d'Espoir and Salmonier (Munro 2001).

\section{Wildfire}

Wildfire has affected every ecoregion in the province, but the majority has occurred in the Central Newfoundland Forest (0.97 million ha) and the Maritime Barrens (0.37 million ha) ecoregions, making up $96 \%$ of the total extent of wildfire disturbance (Table 2). These two ecoregions cover the majority of the interior of the island and have a drier, more continental-influenced climate, creating conditions that are more favourable for wildfire. The Maritime Barrens ecoregion also covers most of the Avalon Peninsula, which is, and was, the major hub of Newfoundland where the majority of people settled in pre-industrial times. The higher population on the Avalon Peninsula led to more recorded anthropogenic wildfires in that region of the province consistently since that time. The effects of fire are well illustrated in the heath barrens of the Avalon Peninsula which are a direct result of burns and re-burns (Ralph 1967). It appears as though the widespread conversion of the forest landscape by European settlers caused a $100 \mathrm{~m}$ depression in the natural forest limit (Meades 1986).

The role of large wildfires in Canada's boreal ecosystem is highly variable from west to east and north to south (Arsenault 2015). Although there is not a lot of published information on fire history in Newfoundland, a consensus seems to emerge that the Central Newfoundland Forest and Maritime Barrens ecoregions are the most fire-prone landscapes on the Island, and that historically, large wildfires have been rare or infrequent (Fig. 3). The first and only comprehensive report by Wilton and Evans (1974) suggested that fire was a dominant factor in "shaping the extent and composition of the forests of Newfoundland." However, they recognized that the oceanic climate of the boreal forest of Newfoundland fostered lower burning rates and fire danger compared with their mainland counterpart. The fire cycle based on standreplacing fires for Newfoundland's boreal was estimated from NRCan's large fire database (1959-2007) to be 769 years (Arsenault 2015) from burning rates estimated in Krezek-Hanes et al. (2011). This rather long fire cycle is consistent with other fire frequency estimates for the Atlantic 


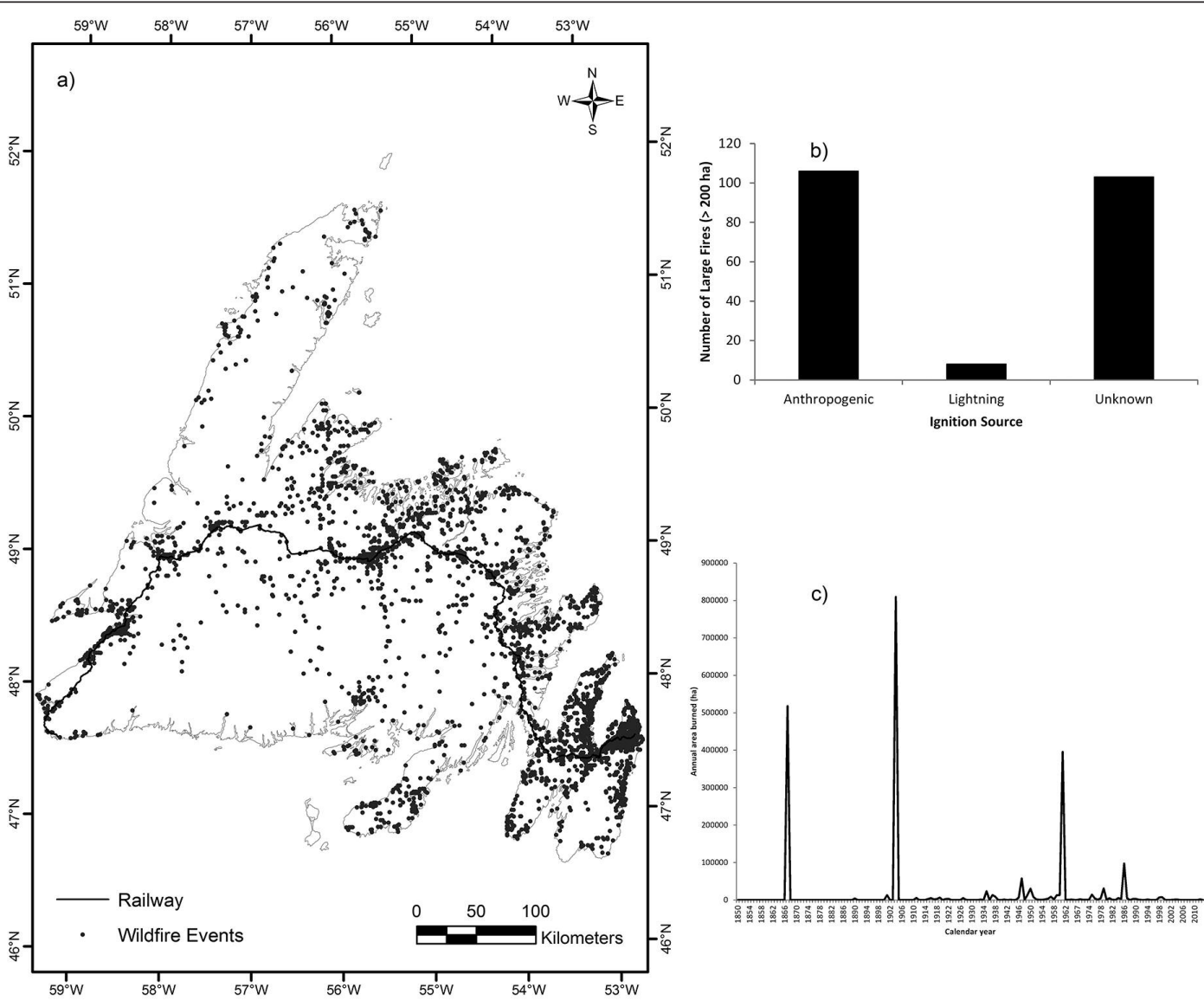

Fig. 3. The spatial and temporal pattern of wildfire: a) map of all fires 1619-2013; b) number of large fires (>200 ha) by ignition source; c) annual area burned 1850-2013.

region, although it should be considered a rough estimate with the caveat that fire frequency varied in time and space in Newfoundland. Foster (1983) estimated fire rotation exceeding 500 years in Labrador, whereas reports for the Acadian forest vary between 200 to over 1000 years (Wein and Moore 1977, 1979).

The temporal pattern of fire history in Newfoundland reveals four major fire years between 1619 and 2013. These are 1867, 1904, 1961, and 1986 (Fig. 3). It is difficult to estimate fire frequency from this distribution because many of the fires were of anthropogenic origin. However, it is pretty clear that natural ignition is generally not common in Newfoundland, which would corroborate fairly long fire cycles as mentioned above. A fire-cycle analysis for Terra Nova National Park in central Newfoundland was calculated using a mean stand age of 97.7 years and suggested that the forests in the park are outside their range of variability due to a lack of fire (Power 1996). There are several problems with this analysis. Firstly, the use of mean age in a fire-cycle model assumes a constant burning rate and that stand ages estimated from the field represent time-since-fire estimates. We suggest that both of these assumptions are not realistic given that many of the stands sampled most likely originated from other disturbance types and that fire records for the general area suggest infrequent fires, which would imply that a constant burning rate is therefore empirically impossible (Huggard and Arsenault 1999). In addition, the suggestion of frequent lightning fires, even in central Newfoundland, is not consistent with the available information. More recently, Bouchard et al. (2008) showed a clear frequency gradient in Quebec linked to continentality. Wilton and Evans (1974) and Damman (1983) observed a similar gradient of fire in Newfoundland. The forests of central Newfoundland (and to some extent the adjacent portions of the Maritime Barrens) are characterized by a "quasi continental climate" and have a richer history of catastrophic fire compared with the wetter western region (Wilton and Evans 1974). This is also consistent with observations by Cormack (1822) who wrote about his foot journey in central Newfoundland: "Roots of large trees, with portions of the trunks attached, and lying near, are sometimes seen occupying evidently the original savanna soil on which they grew, but are now partially, or wholly, covered with savanna fires, originating with the Indians, and from lightning, which have in many parts destroyed the forest; and it would seem that a century or more must elapse in this climate before a forest of the same magnitude of growth can be reproduced naturally on the savannas." The eastern region is characterized by "cool moist climate with frequent oceanic 
fog" (Wilton and Evans 1974). However, moisture in this area is not as evenly distributed as the western region and is more subject to sporadic high fire hazards. These observations are corroborated by charcoal records from paleobotanical studies (Macpherson 1995). Other parts of the island, such as high elevation fir forests, most likely evolved without wildfire (McCarthy 2004). Although it is clear that regional climates are linked to the island's fire history, vegetation may also play a role. Indeed Furyaev et al. (1983) suggested that Abies forests were less flammable than spruce forests, hence creating a feedback mechanism between species composition and fire occurrence. This pattern is clearly reflected in the distribution of balsam fir and black spruce in the less fire-prone region of western Newfoundland compared with central Newfoundland (Fig. 4).

Red pine forests, although considered rare in Newfoundland and at their north eastern limit, offer a unique window on the role of wildfire on the island (Roberts 1985). Red pine trees have thick bark and can survive low to moderate severity fires (Van Wagner 1971b). Many studies have used firescarred red pine trees to reconstruct local fire histories (Bergeron and Brisson 1990) and have concluded a close association between red pine forests and the ecological process of fire (Van Wagner 1971b). The link between red pine and fire is partly related to the biogeography of the species, which is mostly shade intolerant and prefers xeric sites with sandy soils (Roberts 1985). These xeric sites generally are more fire prone and somewhat less susceptible to catastrophic fire due to less continuous fuel distribution. In addition, red pine stands tend to be highly flammable, which creates a paradox of a species that, on the one hand, benefits from fire due to its regeneration requirements, but on the other hand, has "evolved very little to take advantage of fire" (Van Wagner 1971b). However, whether this association translates into "fire dependence", i.e., the species would not survive without fire, is not entirely clear. Roberts and Mallik (1994) and others have spent many years studying the dynamics of red pine forests and fire in Newfoundland. Red pine has been characterized as a shade-intolerant species that often requires fire to regenerate (Bergeron and Gagnon 1987 and many others). Red pine has the ability to survive multiple surface fires, as revealed by fire scars, but is susceptible to severe crown fires (Van Wagner 1971b). Flannigan and Bergeron (1998) found that red pine benefits from semi-regular, moderate-intensity, surface fires, but it is limited by frequent, high-intensity crown fires, the latter being the typical fire of present-day boreal forests on the mainland. They further concluded that fire regimes, rather than climate regimes, are more responsible for determining at least the northward limits of red pine in Quebec. Fire-return intervals in red pine stands vary from as low as five years to more than 300 years (Drobyshev et al. 2008).

In Newfoundland, Roberts and Mallik (1994) found that fire favored seedling regeneration. However, in cases where burned sites are converted to Kalmia heaths, red pine regeneration would be highly unlikely. The reported fire frequency for red pine stands in Newfoundland is inconsistent with our analysis of fire patterns on the island. Roberts and Mallik (1994) report tree ring widths from three cross-sections of one red pine individual at Sandy Lake showing multiple fires. They deduced fire events associated with growth reductions from this one tree and extrapolated a fire cycle of 15 years for red pine stands in Newfoundland. It is difficult to reconcile a 15 -year fire cycle in red pine forests on an island where fires are characterized as rare or infrequent (Krezek-Hanes et al. 2011, Arsenault 2015). An alternative explanation to a constant fire cycle of 15 years is that infrequent fire events have enabled red pine populations to persist in Newfoundland, varying in abundance and extent as a result of the severity of individual fire events and the condition of red pine populations (i.e., size, age structure, seed availability) coinciding with the fire events. If this hypothesis holds true, it would imply that red pine populations are not in a steady state and would be expected to go through major shifts in abundance and extent through time mediated by the spatial and temporal distribution of fire. This idea of fluctuation of pine populations and fire through time is also consistent with the paleobotanical history of the Holocene by Macpherson (1995). This hypothesis may also hold true for other red pine populations on the mainland and is consistent with observations of Flannigan and Bergeron (1998).

\section{The complex human and wildfire interaction in Newfoundland}

A striking difference between the patterns of wildfires in Newfoundland compared with Labrador and other parts of the boreal on the mainland is the ignition source. Although the vast majority of large forest fires in Labrador are from lightning strikes, the opposite is true for Newfoundland (Fig. 3), at least in the last century. Between 1888 and 1988, the Newfoundland railway was a significant ignition source for wildfires, arising from sparks from brake shoes, rail wheels, and hot cinders from locomotives (Newfoundland and Labrador Heritage 2016). For example, in 1952, over 70\% of fires were associated with the railway, whereas only $0.5 \%$ was associated with lightning (Newfoundland Forest Protection Association 1952). Other industrial sources of wildfires included chainsaws and other industrial machinery, and cinders from sawmill boilers. The temporal increase in the number of fires during this period is evident and also corresponds to the largest amount of area burned on record (Fig. 3). Another suggested source of fires near the coast was from fishermen clearing wood and being careless in the woods within the "3-mile limit" where they were given rights to manage land. However, the significance of this practice appears to have been exaggerated (Cadigan 2006). Other sources often listed in the Newfoundland Forest Protection Association annual reports included workers, settlers, smokers, campers, incendiary, berry pickers, and travellers. One of the most severe fire seasons in Newfoundland occurred in 1904, where fires, often triggered by the railway, burned extensively from coast to coast. This intensive level of conflagration resulted in the establishment of a fire suppression unit in 1905, which later became the Newfoundland Forest Service (Wilton and Evans 1974). The initial suppression unit consisted of patrols with shovels and buckets, some targeted specifically toward the railway. Crews patrolled 386 miles of the railway, and were successful in extinguishing over 10000 fires (Cooper 1937). The combination of the cessation of the Newfoundland railway, contemporary and well-coordinated fire suppression activities using aggressive initial attack, and public education and enforcement of fire prevention regulations appear to have resulted in a significant reduction of large wildfires in the last two decades (Fig. 3), but this could also be, at least in part, associated with fire weather. Contempo- 


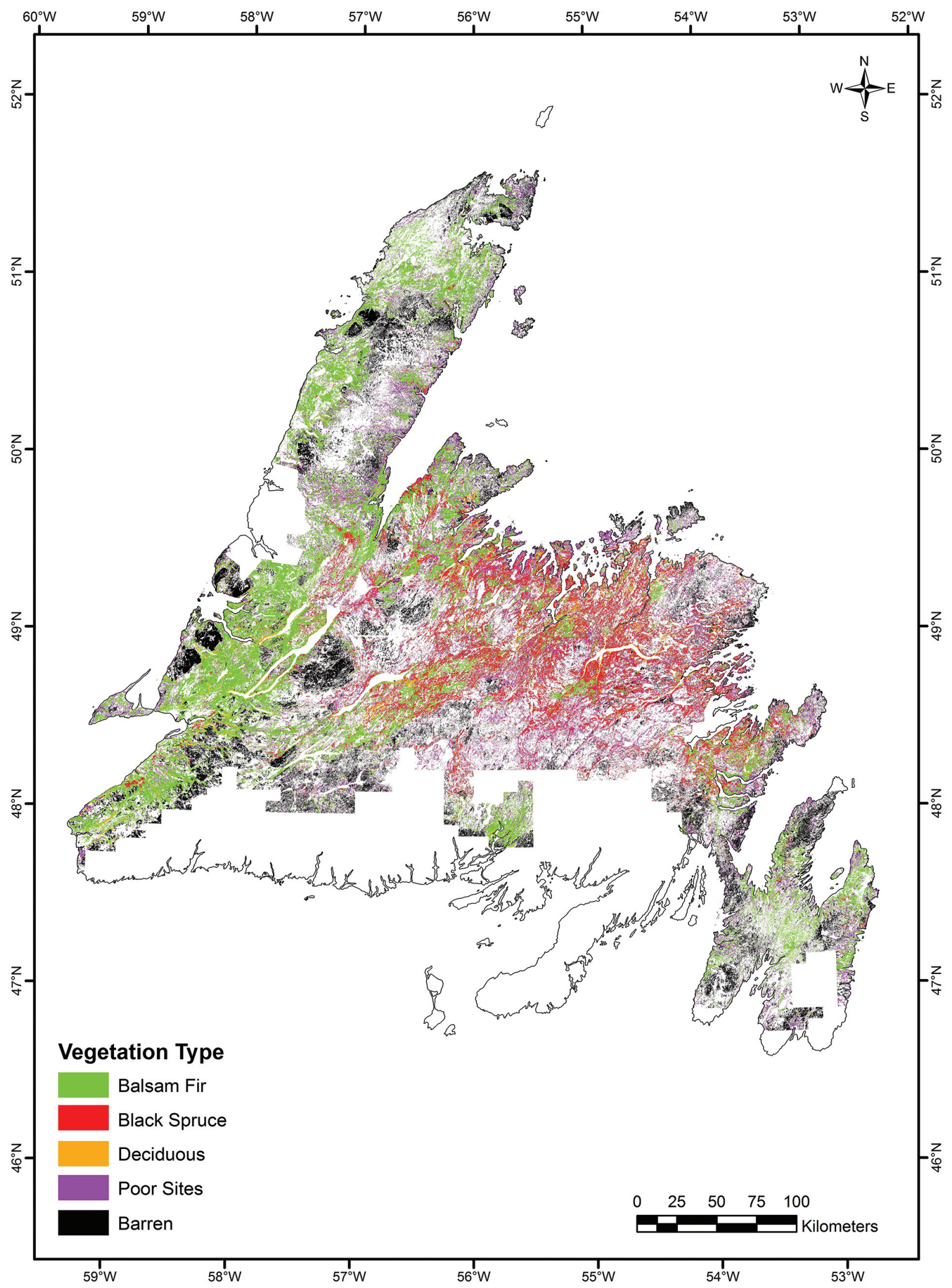

Fig. 4. Dominant vegetation types. 
rary fire management in Newfoundland also consists of prescribed burning conducted by Parks Canada in Terra Nova National Park and by the Newfoundland Forest Service to meet silviculture objectives, particularly in mature fir stands infested by the balsam woolly adelgid. Climate change is predicted to increase the length of the fire season in most of Canada's boreal forest, which could lead to an increase in large wildfires and fires of anthropogenic origin if ignitions occur during high fire risk windows (Bergeron et al. 2010). The potential for wildland-urban interface fires has increased significantly in recent years. As people in the province of Newfoundland and Labrador move into forested regions as a place to live, as well as to recreate, the threat from large uncontrolled fires becomes greater. The interface presents significant challenges in wildfire management as evidenced in the recent 2013 wildfires in Wabush, Labrador.

\section{Insects}

A very high proportion of Newfoundland's forests have been affected by defoliating insects during the last century (Fig. 2). The two most important insect defoliators are the ESB and the HL. During the last ESB outbreak from 1972 to 1992, 90\% of the productive forest land base in Newfoundland was affected by this insect. The ESB was first described in Maine in 1807 (Kucera and Orr 1980) and in Newfoundland in 1945 (Kennedy et al. 1955). Populations of ESB are cyclic, with a periodicity of 33 years at the supra-regional scale (Morin et al. 2007). This actually matches our temporal reconstruction of the outbreaks in Newfoundland (Fig. 5), although the 1950s outbreak was most likely dominated by light defoliation that would have not resulted in significant tree mortality. Morin et al. (2007) have reported alternating levels of defoliation severity between outbreaks. Before the devastating ESB outbreak during the 1970s, Kennedy et al. (1955) stated that there was no evidence that ESB ever reached epidemic levels in Newfoundland except for small outbreaks in Bowring Park and Bell Island. The lack of published evidence on historical ESB outbreaks before the massive one of the late 1970s is intriguing, and most likely a result of lack of surveying effort. Blais (1983) suggested that Quebec's north shore region and Newfoundland share a similar history of ESB outbreaks. Dendrochronological and paleoecological evidence for the adjacent province of Quebec clearly shows that this insect has been present in eastern North America for centuries to millennia (Simard et al. 2006, Morin et al. 2007). In Newfoundland, radial growth reductions associated with ESB defoliation outbreaks are visible over several centuries (Jardon and Doyon $2003^{2}$ ). Some of the dates of growth reductions match similar patterns for Anticosti Island and Quebec's north shore (Barrette et al. 2010), indicating a synchrony in outbreaks in Newfoundland with other ESB populations in eastern Canada. The ESB spatial records cover the complete cycle of the devastating outbreak that occurred throughout the 1970s and 1980s. The footprint covered approximately 4.09 million

\footnotetext{
${ }^{2}$ Jardon, Y. and F. Doyon. 2003. Balsam fir stand dynamics after insect outbreak disturbances in Western Newfoundland Ecoregion (Corner Brook subregion). Joint publication of the Model Forest Network, Natural Resources Canada - Canadian Forest Service, the Institut Québécois d'Aménagement de la Forêts Feuillue, the Corner Brook Pulp and Paper Ltd., and the Department of Forest Resources and Agrifoods, Newfoundland and Labrador Forest Service.
}

ha of forest across the island (Table 2; Fig. 2), which is more than all other disturbances combined. Forests with inferred mortality would be approximately one-quarter of the ESB footprint, which was estimated by mapping stands with at least three or more years of consecutive moderate to severe defoliation (Fig. 5). The areas with high mortality would result in stand-replacing events, whereas the ones with moderate severity could result in mixed-age stands.

Hemlock looper is also a significant insect pest, and although it has impacted less area overall, the forests can be more severely affected due to their feeding habits. Hemlock looper records span multiple outbreaks and cover an area of approximately 1.3 million ha. The temporal and spatial patterns of defoliation by the HL (Fig. 6) also appear more regular and easier to predict in Newfoundland, occurring approximately every $15-20$ years and moving in a semi-circle pattern from south to north.

Both ESB and HL have cyclical behavior and are closely associated with climatic variations. Therefore, they can be expected to return to outbreak conditions very soon, and climate change may exacerbate the situation (LeBlanc et al. $2013^{3}$ ). Although the records of other defoliating insects are limited (Table 1), their importance should not be overlooked. The balsam fir sawfly (BFS), for instance, has disturbed 0.32 million ha of forest (Table 2) from 1997-2010 (Table 1), and is a serious problem, especially in western Newfoundland, where there is an abundance of balsam fir, the preferred host species (NRCan 2015). The yellow-headed spruce sawfly, rusty tussock moth, and the spruce bud moth have relatively small footprints when compared with the other defoliating insects, but this is likely due to lack of data collection on these species, as ESB, HL, and BFS pose greater risks of disturbance and demand more attention. Nonetheless, the yellow-headed spruce sawfly, rusty tussock moth, and spruce bud moth could have major impacts at the regional scale if outbreak conditions occur.

\section{Wind}

Due to the fact that Newfoundland is an island in the North Atlantic, wind plays a significant role in all regions, especially the Maritime Barrens ecoregion ( 0.12 million ha; $28 \%$ of the windthrow disturbance footprint), which covers the majority of the Avalon Peninsula and the south coast of the island. Coastal areas and places near mountain ranges (i.e., the Wreckhouse area along the Long Range Mountains of southwestern Newfoundland) also have significantly high winds throughout the entire year.

The shallow rooting of most boreal tree species, particularly in combination with shallow soils and major wind events around the island, renders much of the forest prone to wind damage. Weakened tree vigor and rooting systems often lead to windthrow following insect defoliation, which opens stands up as a result of tree mortality or other stressors. Detailed interpretation of 1996 satellite imagery of the Avalon Peninsula showed 4650 ha of forest blowdown in 1994-1995, much of which was in areas affected by the HL outbreak of

$\overline{{ }^{3} \text { LeBlanc, R., D. Brooks and A. Arsenault. 2013. Spatial analysis of }}$ historical spruce budworm and hemlock looper outbreaks for the island of Newfoundland. Poster presented at the CIF/IFC AGM in Corner Brook, September 2013. 


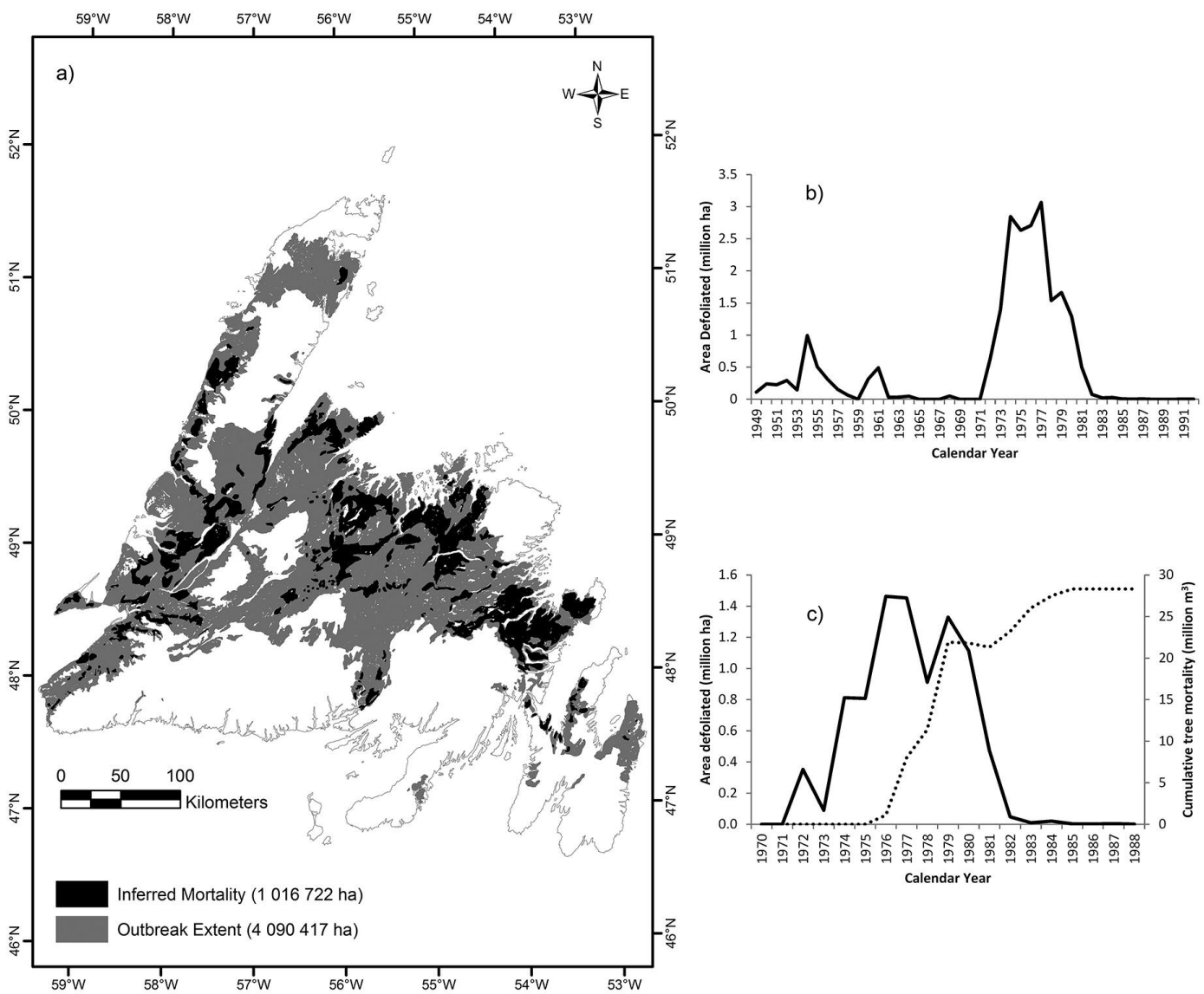

Fig. 5. The spatial and temporal pattern of eastern spruce budworm defoliation: a) map of the largest outbreak on record $1972-1992$ (total extent in grey, inferred mortality in black); b) annual area defoliated from 1949-1992 using all defoliation categories (light, moderate, and severe); c) annual area defoliated (moderate and severe defoliation potentially resulting in mortality; solid line) and cumulative tree mortality (dotted line) during the 1970s outbreak.

1984. Wave forests due to wind action have been described in five locations in Newfoundland, although previously reported only in high alpine forests in the northeastern USA and subalpine forests in Japan. One wave forest on the Northern Peninsula is reported to extend over an area of greater than $100 \mathrm{~km}^{2}$ (Robertson 1987). The edge of a wave forest can advance at a rate of 15-20 m per year (Robertson 1994).

\section{Synergistic effects}

Some synergistic effects have been observed between disturbances, increasing the resulting severity or size. For example, clear cutting exposes forest edges, which become more vulnerable to windthrow. In Newfoundland, this is observed frequently in riparian retention corridors (Glode 2009). The Avalon Forest ecoregion is subjected to considerable windstorms, and large clearcutting is discouraged (Meades and Moores 1994, Planning Team for Forest Ecosystem Management on the Avalon 2002). Windstorms can also cause root damage in pre-commercially thinned stands, creating a feedback loop that leads to increases in root rot and making the stands more susceptible to windthrow (Whitney et al. 2002, Warren et al. 2013). Severe insect defoliation is often followed by windthrow in the Avalon Forest ecoregion, which increases disturbance severity. In the case of ESB, Taylor and MacLean (2009) describe a similar pattern in New Brunswick but with a lag between the end of the outbreak and the windthrow events. Grégoire and Quiring (2015) have shown that the balsam woolly adelgid changes the host plant quality, which in turn affects ESB population growth. Trees weakened by insect pests can also be more vulnerable to Armillaria root disease (Hudak and Singh 1970, Ostaff 1983).

\section{Management Implications}

The historical pattern of disturbances affecting Newfoundland's forests is complex, involving interactions between natural and anthropogenic disturbances for more than 100 years. We hypothesize that during the pre-industrial era, fires were infrequent due to low probability of natural ignition. However, when optimal burning conditions and ignition sources coincided, fire could be very extensive and severe, particularly in the more continental regions of central Newfoundland and the Maritime Barrens. This probably explains, at least in part, the historical abundance of black spruce and eastern white pine on good sites in central Newfoundland and the restriction of red pine to this region. Although very long intervals between fire events can translate into an abundance of old- 

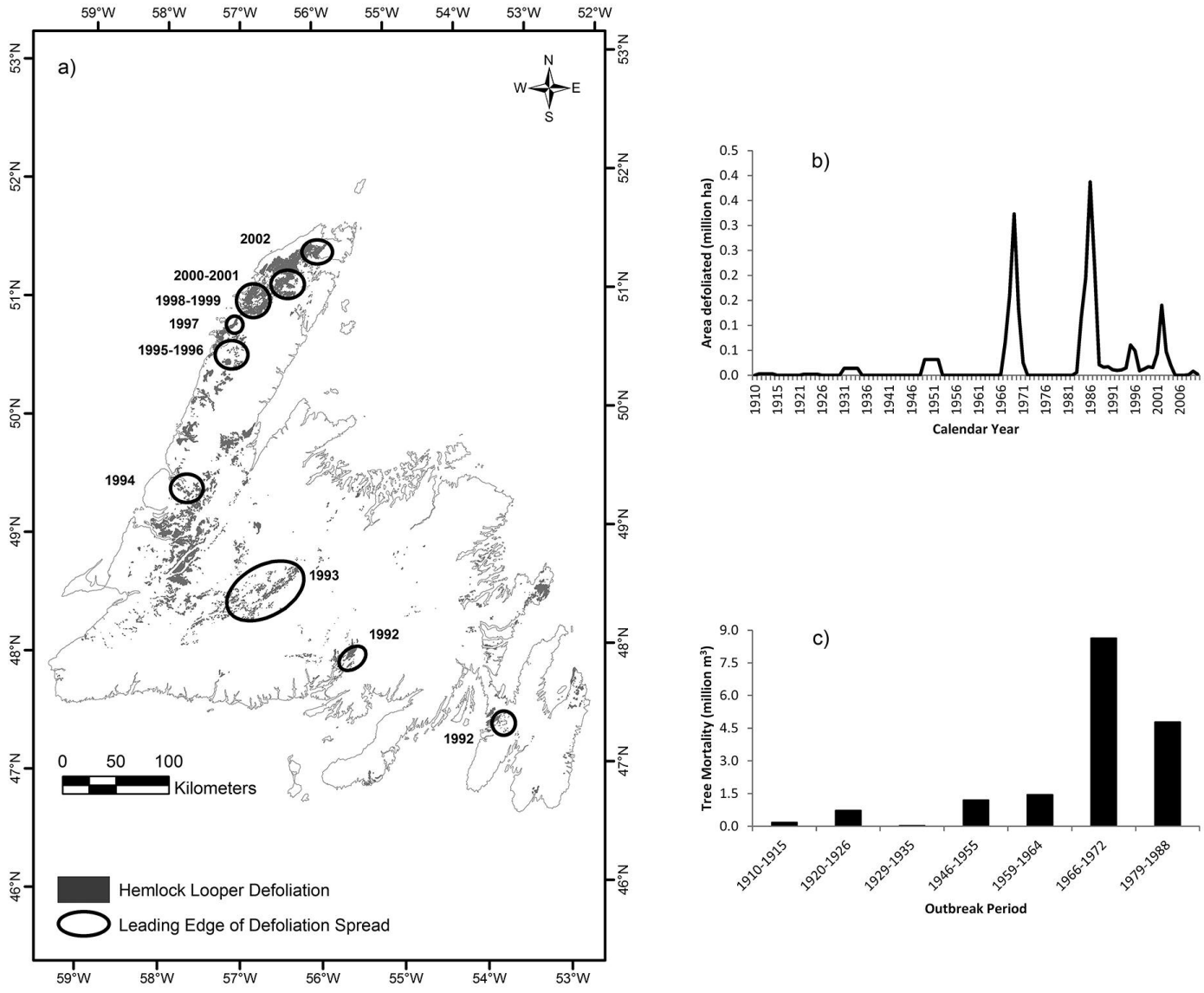

Fig. 6. The spatial and temporal pattern of hemlock looper defoliation: a) spread of a typical hemlock looper outbreak; b) annual area defoliated from 1910-2010 c) cumulative tree mortality within each outbreak period

growth forests, the more frequent disturbance by insect defoliators would have created a highly patchy landscape with mosaics of different ages and, possibly, mixed-age stands of varying sizes in forest landscapes (McCarthy and Weetman 2007), similar to the pre-industrial conditions described for Anticosti Island (Barrette et al. 2010). For example, McCarthy and Weetman (2006) point to exceptionally old forests (> 230-year-old balsam fir) at high elevations in Newfoundland, and we have found many old forest stands containing eastern white pine older than 300 years in central and western Newfoundland (Arsenault, unpublished data). The interaction of multiple disturbances, such as insect defoliators, root disease, and windthrow, would result in higher cumulative severity, hence higher tree mortality and initiate new even-aged patches, whereas forests affected by extensive disturbance of low to moderate intensity, i.e., three-quarters of the last ESB outbreak, would likely result in a thinning from above, creating a mixed-age structure. The level of tree mortality and changes resulting from different disturbances will be modulated by disturbance metrics (i.e., type, magnitude, spatial and temporal distribution), site characteristics, and by tree species composition before the outbreak. The last outbreak (in Quebec) gave rise to a gradient of stand-regeneration patterns, depending on species composition before the outbreak and host and non-host mortality following it, ranging from overall stand mortality and replacement in balsam fir-dominated stands, dual-cohort structures in mixed boreal stands where mortality was partial, and quasi-gap dynamics in mixed hardwood stands dominated by yellow birch (Bouchard et al. 2005).The two most important differences between preindustrial conditions and today's managed landscapes would be higher historical amounts of old-growth forests and levels of deadwood. This view differs somewhat from the interpretation of Brown and Wells (unpublished), who suggested that pre-industrial conditions were characterized by large expanses of even-aged stands. We are currently conducting additional analyses using complementary lines of evidence to get a more in-depth resolution of forest conditions resulting from different disturbances in Newfoundland.

Although the idea of emulating natural disturbances in contemporary forestry operations is well intentioned, we suggest that it will be challenging in Newfoundland and probably for the rest of Canada as well. For example, creating very large clear cuts to emulate large fire events would most likely create several problems for ecosystem services, including water and habitat. Furthermore, creating extensive selective logging disturbances to mimic a defoliating disturbance would be imprudent from an ecological and economical perspective. Finally, it is important to recognize that all forest ecosystems, both young and old, have value, and that a young clearcut forest may be very different than a young forest recovering from a natural disturbance. The incorporation of NRV (Natural 
Range in Variation) in forest management and planning has recently become a requirement under the Canadian Boreal Forest Agreement and Forest Stewardship Council for participating forest companies. We recognize that the goals of using NRV are good, but there are serious issues in how this can be done operationally within a science-based context. Key operational challenges associated with the implementation of this initiative include the uncertainty and fluctuating temporal benchmarks associated with historical conditions, the difficult application of mimicking extreme events, and the lack of clear and specific objectives. We suggest that integrating local knowledge from NRV analyses such as those presented in this paper with other key information such as patterns of biodiversity and wildlife habitat requirements into an adaptive forest management plan has merit. However the assumptions and uncertainty associated with this information should be clearly articulated and presented in a transparent manner. For example, for this study, we clearly state the limitations of our historical data set especially for older records. Although we are confident that the patterns we have described are accurate, the absence of specific disturbances at certain places at certain times remains a source of uncertainty that we are addressing using paleo-ecological and dendro-ecological approaches.

Understanding the resilience of forests emerging from different anthropogenic and natural disturbances is critical in order to develop rigorous ecosystem-based management plans. For example, Thompson et al. (2003) compared old unmanaged forests with young managed forests in western Newfoundland and found some similarities but also important differences in structure and composition. Although it is useful to understand these differences, it would be equally important to know what the difference is between forests of similar ages resulting from different disturbances or examining forests of different ages resulting from the same type of disturbance to evaluate forest ecosystem resilience and rate of recovery. A combination of specific objectives and ecological principles, such as ecosystem representation, redundancy, and connectivity, and knowledge on species habitat requirements, should be used to guide the application of NRV information in forest management. If a science-based approach is desired, assumptions about NRV should be tested using a rigorous experimental design. We encourage the establishment of large-scale experiments, similar to silviculture systems studies in British Columbia (Klenner and Arsenault 2006), in at least a portion of forestry operations to enable an ecosystem science-based approach. Although it may not be feasible to monitor these experiments in the short term, they will provide a legacy of replicated experimental designs over managed areas that can help provide answers over the long term.

\section{Acknowledgments}

Many people have helped provide data and insight. In particular, we would like to thank Blair Adams, Boyd Pitman and Peggy Sullivan from Newfoundland and Labrador Forest Service, and Louis DeGrandpré, Brian Eddy, Doug Piercey, Caroline Simpson, Guy Strickland, Olivier van Lier, Joan Luther, Darrell Harris, and Bill Meades from the Canadian Forest Service. Wayne Brown and Doyle Wells generously provided their views and suggestions about the discrepancy between their report and our paper for which we are grateful. We also warmly thank Dr. Ron Ayling and two anonymous reviewers for good suggestions and a thorough review of our manuscript.

\section{References}

Acuna, M.A., C.D. Palma, W. Cui, D.L. Martell and A. Weintraub. 2010. Integrated spatial fire and forest management planning. Can. J. For. Res. 40(12): 2370-2383.

Armstrong, J.A. and W.G.H. Ives (eds.). 1995. Forest insect pests in Canada. Nat. Res. Can., Can. For. Serv., HQ, Sci. Sust. Dev. Dir., Ottawa, ON. 732 p.

Arsenault, A. 1995. Pattern and process in old-growth temperate rainforests of southern British Columbia. Ph.D. thesis, Department of Botany, The University of British Columbia, Vancouver, BC.

Arsenault, A. 2015. The role of large fires in the Canadian boreal ecosystem. In D.A. DellaSala and C.T. Hanson (eds.). The ecological importance of mixed-severity fires: nature's phoenix. pp. 247-264. Elsevier, Amsterdam.

Arsenault, A. and G.R. Larocque. 2016. Indicators of forest ecosystem integrity. In Larocque G.R. (ed.) Ecological forest management handbook, 361-380. CRC Press, Boca Raton, FL.

Balch, R.E. and W.J. Carroll. 1958. Le puceron lanigère du sapin baumier. Service des sciences - Division de la biologie forestière. M. d. l'agriculture. Ottawa, Edmond Cloutier, Imprimeur de la reine et contrôleur de la papeterie. 977: 8 p

Barrette, M., L. Belanger and L. De Grandpre. 2010. Preindustrial reconstruction of a perhumid midboreal landscape, Anticosti Island, Quebec. Can. J. For. Res. 40(5): 928-942.

Batterson, M.J., D.G.E. Liverman and D.M. Taylor. 1995. The assessment of geological hazards and disasters in Newfoundland. In Current research, Newfoundland and Labrador Department of Natural Resources Geological Survey Report 95-1. pp. 55-75.

Bergeron, Y. and D. Gagnon. 1987. Age structure of red pine (Pinus resinosa Ait.) at its northern limit in Quebec. Can. J. For. Res. 17: 129-137.

Bergeron, Y. and J. Brisson. 1990. Fire regime in red pine stands at the northern limit of the species' range. Ecology 71(4): 1352-1364.

Bergeron, Y. and N.J. Fenton. 2012. Boreal forests of eastern Canada revisited: old growth, nonfire disturbances, forest succession, and biodiversity. Botany 90(6): 509-523.

Bergeron, Y., D. Cyr, M.P. Girardin and C. Carcaillet. 2010. Will climate change drive $21^{\text {st }}$ century burn rates in Canadian boreal forest outside of its natural variability: collating global climate model experiments with sedimentary charcoal data. Int'l J. Wildland Fire 19: 1127-1139.

Bergerud, A.T. and F. Manuel. 1968. Moose damage to balsam firwhite birch forests in central Newfoundland. J. Wildl. Manage. 32(4): 729-746.

Blais, J.R. 1983. Trends in the frequency, extent, and severity of spruce budworm outbreaks in eastern Canada. Can. J. For. Res. 13: 539-547.

Blais, J.R., E.G. Kettela and B.H. Moody. 1981. History of spruce budworm outbreaks in eastern North America with special reference to Newfoundland. In J. Hudak and A.G. Raske (eds.). Review of the spruce budworm outbreak in Newfoundland - its control and forest management implications: Canadian Forestry Service submission to the Newfoundland and Labrador Royal Commission on Forest Protection and Management. pp. 12-17. Nat. Res. Can., Can. For. Serv. - Nfld Inf. Rep. N-X-205.

Botkin, D.B. 1990. Discordant harmonies: a new ecology for the twenty-first century. Oxford University Press, Oxford, United Kingdom.

Bouchard, M., D. Kneeshaw and Y. Bergeron. 2005. Mortality and stand renewal patterns following the last spruce budworm outbreak in mixed forests of western Quebec. For. Ecol. Manage. 204: 297-313. Bouchard, M., D. Pothier and S. Gauthier. 2008. Fire return intervals and tree species succession in the North Shore region of eastern Quebec. Can. J. For. Res. 38(6): 1621-1633. 
Cadigan, S. 2006. Recognizing the commons in coastal forests: the three-mile limit in Newfoundland, 1875-1939. Nfld. Labr. Stud. 21(2): 1-15.

Carroll, W.J. and D.G. Bryant. 1960. A review of the balsam woolly aphid in Newfoundland. For. Chron. 36(3): 278-290.

CBFA. 2015. Towards a natural range of variation (NRV) strategy for the Canadian Boreal Forest Agreement - summary report. CBFA, Ottawa, ON.

Cooper, L.R. 1937. Fire patrol of Newfoundland. In J.R. Smallwood (ed.). The book of Newfoundland: Volume 2. P. 316. Newfoundland Book Publishers Ltd., St. John's, NF, Canada.

Cormack, W.E. 1822. Narrative of a journey across the Island of Newofundland in 1822. Edited by F.A. Bruton and republished 1928. Longmans, Green Co., London and New York. 138 p.

Damman, A.W.H. 1983. An ecological subdivision of the island of Newfoundland. In G.R. South (ed.). Biogeography and ecology of the island of Newfoundland, Monographie Biologicae 48. pp. 163-206. Dr. W. Junk Publishers, The Hague, Netherlands.

Donato, D.C., J.B. Fontaine, J.L. Campbell, W.D. Robinson, J.B. Kauffman and B.E. Law. 2006. Post-wildfire logging hinders regeneration and increases fire risk. Science 311: 352.

Drobyshev, I., P.C. Goebel, D.M. Hix, R.G. Corace III and M.E. Semko-Duncan. 2008. Pre- and post-European settlement fire history of red pine-dominated forest ecosystems of Seney National Wildlife Refuge, Upper Michigan. Can. J. For. Res.38: 2497-2514.

Flannigan, M. and Y. Bergeron. 1998. Possible role of disturbance in shaping the northern distribution of Pinus resinosa. J. Veg. Sci. 9: 477-482.

Forestry Canada Fire Danger Group. 1992. Development and structure of the Canadian Forest Fire Behavior Prediction System. Nat. Res. Can., Can. For. Serv., Sci. Sust. Dev. Dir., Ottawa, Ontario, Canada. Inf. Rep. ST-X-3.

Foster, D. 1983. The history and pattern of fire in the boreal forest of southeastern Labrador. Can. J. Bot. 61(9): 2459-2471.

Foster, D.R., D.A. Orwig and J.S. McLachlan. 1996. Ecological and conservation insights from reconstructive studies of temperate oldgrowth forests. Trends Ecol. Evol. 11(10): 419-424.

FSC Canada. 2015. Range for natural variation. FSC Canada, Toronto, ON.

Furyaev, V.V., R.W. Wein and D.A. MacLean. 1983. Fire influences in Abies-dominated forests. In R.W. Wein and D.A. MacLean (eds.).The role of fire in northern circumpolar ecosystems. pp. 221-234. John Wiley \& Sons Ltd, New York, USA.

Glode, J. 2009. Predicting windthrow in riparian zones in insular Newfoundland. M.Sc. thesis, Faculty of Forestry and Environmental Management, The University of New Brunswick, Fredericton, New Brunswick, Canada.

Grégoire, D.M. and D.T. Quiring. 2015. Indirect host-mediated effects of an exotic phloem-sap feeder on a native defoliator of balsam fir. For. Ecol. Manage. 341: 1-7

Grumbine, R.E. 1994. What is ecosystem management? Conserv. Biol. 8(1): 27-38.

Hardy, Y., M. Mainville and D.M. Schmitt. 1986. An atlas of spruce budworm defoliation in eastern North America, 1938-80. USDA Forest Service Miscellaneous Publication Number 1449.

Hudak, J. and P. Singh. 1970. Incidence of Armillaria root rot in balsam fir infested by balsam woolly aphid. Can. Plant Disc. Surv. 50: 99-101.

Huggard, D.J. and A. Arsenault. 1999. Reverse cumulative standing age distribution in fire frequency analysis. Can. J. For. Res. 29: 1449-1456.

Jordan, P., K. Turner, D. Nicol and D. Boyer. 2006. Developing a risk analysis procedure for post-wildfire mass movement and flooding in British Columbia. First specialty conference on disaster mitigation, 23-26 May 2006. pp. 1-10. Calgary, Alberta, Canada. Canadian Society of Civil Engineers Publ. DM-013, Montreal, QC.

Kaufmann, M.R., T.T. Veblen and W.H. Romme. 2007. Historical fire regimes in ponderosa pine forests of the Colorado Front Range, and recommendations for ecological restoration and fuels management. Colorado Forest Restoration Institute.

Kennedy H., D.R. Cameron and R.C. Goodyear. 1955. Report of the Newfoundland Royal commission on forestry. David R. Thistle, Printer to the Queen's Most Excellent Majesty. 240 p.

Klenner, W. and A. Arsenault. 2006. Forest management options for Interior dry forest ecosystems: The Opax Mt. and Isobel research trials. Extension Note - RSI 5. 10 p.

Klenner, W., R. Walton and V. Kurz. 1999. Habitats for tomorrow: understanding the consequences of today's decisions and natural disturbances on future habitat condition. In L.M. Darling (ed.). Proceedings of a Conference on the Biology and Management of Species and Habitats at Risk, Kamloops, British Columbia, Canada, 15-19 February 1999. pp. 199-205. Volume One, British Columbia Ministry of Environment, Lands and Parks, Victoria, BC and University College of the Cariboo, Kamloops, BC.

Klenner, W., R. Walton, A. Arsenault and L. Kremsater. 2008. Dry forests in the Southern Interior of British Columbia: historic disturbances and implications for restoration and management. For. Ecol. Manage. 256: 1711-1722.

Krezek-Hanes, C.C., F. Ahern, A. Cantin and M.D. Flannigan. 2011. Trends in large fires in Canada, 1959-2007. Available from the Canadian Councils of Resource Ministers, Ottawa, ON. Canadian biodiversity: ecosystem status and trends 2010, Technical Thematic Report No. 6. http://www.biodivcanada.ca/default.asp?lang=En\&n= 83A35E06-1

Kucera D.R. and P.W. Orr. 1980. Spruce budworm in the eastern United States. Available from the U.S. Department of Agriculture, Forest Service. Forest Insect \& Disease Leaflet 160.

Leroux, S.J., F.K.A. Schmiegelow, R.B. Lessard and S.G. Cumming. 2007. Minimum dynamic reserves: a framework for determining reserve size in ecosystems structured by large disturbances. Biol. Conserv. 138: 464-473.

Lesica, P. 1996. Using fire history models to estimate proportions of old growth forest in northwest Montana, U.S.A. Biol. Conserv. 77: 33-39.

Lindenmayer, D.B. and G.E. Likens. 2009. Adaptive monitoring: a new paradigm for long-term research and monitoring. Trends. Ecol. Evol. 24: 482-486.

Liverman, D., M. Batterson, D. Taylor and J. Ryan. 2000. Geological hazards and disasters in Newfoundland and Labrador. Can. Geotech. J. 38: 936-956.

Macpherson, J.B. 1995. A 6 KA BP reconstruction for the Island of Newfoundland from a synthesis of Holocene lake-sediment pollen records. Geogr. Phys. Quat. 49(1): 163-182.

Martell, D.L. 1996. Old-growth, disturbance, and ecosystem management: Commentary. Can. J. Bot. 74: 509-510.

McCarthy, J.W. 2004. Natural disturbance and structure in two primary boreal forests of western Newfoundland. Ph.D. thesis, Faculty of Forestry, The University of British Columbia, Vancouver, BC.

McCarthy, J.W. and G. Weetman. 2006. Age and size structure of gap-dynamic, old-growth boreal forest stands in Newfoundland. Silv. Fenn. 40: 209-230.

McCarthy, J.W. and G. Weetman. 2007. Stand structure and development of an insect-mediated boreal forest landscape. For. Ecol. Manage. 241: 101-114.

Meades, W.G. 2008. Vegetation of Newfoundland. In S.S. Talbot (ed.). Proceedings of the Fourth International Conservation of Arctic Flora and Fauna (CAFF) Flora Group Workshop, 15-18 May 2007, Tórshavn, Faroe Islands. CAFF Technical Report No. 15. pp. 16-20 Akureyri, Iceland.

Meades, W.J. 1986. Successional status of ericaceous dwarf-shrub heath in Eastern Newfoundland. Ph.D. thesis, The University of Connecticut, Storrs, CT.

Meades, W.J. and L. Moores. 1994. Forest site classification manual: a field guide to the Damman forest types of Newfoundland. FRDA Report 003, Nat. Res. Can., Can. For. Serv. and Dept. For. Agric., Newfoundland. 
Morin, H., Y. Jardon and R. Gagnon. 2007. Relationship between spruce budworm outbreaks and forest dynamics in eastern North America. In E.A. Johnson and K. Miyanishi (eds.). Plant disturbance ecology: the process and the response. Academic Press, Burlington, MA.

Munro, J.A. 2001. Pitprops and pulpwood: a history of export wood operations in Newfoundland and Labrador 1898-1992. Government of Newfoundland and Labrador.

Newfoundland and Labrador Department of Natural Resources. 2014. Growing our renewable and sustainable forest economy provincial sustainable forest management strategy 2014-2024. NLDNR, Corner Brook, NL.

Newfoundland and Labrador Heritage. 2016. Transportation and land-based industries. [online] Available from http://www.heritage. nf.ca/articles/economy/transportation-impacts.php [accessed 3 February 2016].

Newfoundland Forest Protection Association. 1952. Annual report of the Newfoundland Forest Protection Association to the annual meeting, November 1952.

NRCan. 2015. Balsam fir sawfly (factsheet). Natural Resources Canada, Ottawa, Ontario. [online] Available from https://tidcf nrcan.gc.ca/en/insects/factsheet/6564 [accessed 19 January 2016].

Ostaff, D.P. 1983. A wood quality study of dead and dying balsam fir-the incidence of armillaria root rot. Nat. Res. Can., Can. For. Serv. - Atl. For. Ctr., Tech. Note 82, Fredericton, NB, 3 p.

Otvos, I.S., L.J. Clarke and D.S. Durling. 1979. A history of recorded eastern hemlock looper outbreaks in Newfoundland. Nat. Res. Can., Can. For. Serv. - Atl. For. Ctr. Inf. Rep. N-X-179.

Payette, S. 1992. Fire as a controlling process in the North American boreal forest. In H.H. Shugart, R. Leemans and G.B. Bonan (eds.). A systems analysis of the global boreal forest. Cambridge University Press, New York, NY.

Payne, N.F. 1976. Red squirrel introduction to Newfoundland. Can. Field Natur. 90: 60-64.

Planning Team for Forest Ecosystem Management on the Avalon. 2002. Forest ecosystem strategy document for forest management District 1 (The Avalon Peninsula). $106 \mathrm{p}+$ maps

Power, R.G. 1996. Forest fire history and vegetation analysis of Terra Nova National Park. Parks Canada Technical Reports in Ecosystem Science. Report No. 004. Ottawa, Canada.

Quiring, D., D. Ostaff, L. Hartling, D. Lavigne, K. Moore and I. DeMerchant. 2008. Temperature and plant hardiness zone influence distribution of balsam woolly adelgid damage in Atlantic Canada. For. Chron. 84(4): 558-562.

Ralph, E. 1967. The forests of Newfoundland and Labrador. In J.R. Smallwood (ed.). The book of Newfoundland, Volume 3. pp 338-345. Newfoundland Book Publishers Ltd. St. John's, NF.

Rametsteinera, E. and M. Simula. 2003. Forest certification-an instrument to promote sustainable forest management? J. Environ. Manage. 67: 87-98.

Roberts, B.A. 1985. Distribution and extent of Pinus resinosa Ait. in Newfoundland. Rhodora 87: 341-356.

Roberts, B.A. and A.U. Mallik. 1994. Responses of Pinus resinosa in Newfoundland to wildfire. J. Veget. Sci. 5: 187-196

Robertson, A. 1987. The centroid of tree crowns as an indicator of abiotic processes in a balsam fir wave forest. Can. J. For. Res. 17: 746-755

Robertson, A. 1994. Directionality, fractals and chaos in windshaped forests. Agric. For. Meteorol. 72(1-2): 133-166.

Robichaud, P.R. and L.E. Ashmun. 2012. Tools to aid post-wildfire assessment and erosion-mitigation treatment decisions. Int'l. J. Wildland Fire 22(1): 95-105.

Simard, I., H. Morin and C. Lavoie. 2006. A millennial-scale reconstruction of spruce budworm abundance in Saguenay, Quebec, Canada. The Holocene 6: 31-37.
Simpson, R. A.and D. Coy. 1999. An ecological atlas of forest insect defoliation in Canada 1980-1996. Nat. Res. Can., Can. For. Serv. Atl. For. Ctr., Fredericton, NB. Inf. Rep. M-X-206E

Sprugel, D.G. 1991. Disturbance, equilibrium, and environmental variability: what is 'natural' vegetation in a changing environment? Biol. Conserv. 58(1): 1-18.

Sterner, T.E. and A.G. Davidson. 1981. Forest insect and disease conditions in Canada 1980. FIDS report, Nat. Res. Can., Can. For. Serv., Ottawa, ON.

Stocks, B.J., J.A. Mason, J.B. Todd, E.M. Bosch, B.M Wotton, B.D. Amiro, M.D. Flannigan, K.G. Hirsch, K.A. Logan, D.L. Martell and W.R. Skinner. 2002. Large forest fires in Canada, 1959-1997. J. Geophys. Res. 107(D1): FFR 5-1 - FFR 5-12.

Taylor, S.L. and D.A. MacLean. 2009. Legacy of insect defoliators: Increased wind-related mortality two decades after a spruce budworm outbreak. For. Sci. 55(3):: 256-267.

Thompson, I.D. and W.J. Curran. 1992. Influence of moose browsing on successional forest growth on black spruce sites in Newfoundland. For. Ecol. Manage. 47(1-4): 29-37.

Thompson, I.D., D.J. Larson and W.A. Montevecchi. 2003. Characterization of old "wet boreal" forests, with an example from balsam fir forests of western Newfoundland. Environ. Rev. 11: S23-S46.

Thoms, J.R. 1967. The sawmill pioneers of Newfoundland. In J.R. Smallwood (ed.). The book of Newfoundland, Volume 4. pp 417-429. Newfoundland Book Publishers Ltd. St. John's, Newfoundland, Canada.

Turner, J. 1937. The forests of Newfoundland. In J.R. Smallwood (ed.). The book of Newfoundland, Volume 1. pp 58-62. Newfoundland Book Publishers, Ltd. St. John's, Newfoundland, Canada.

van Nostrand, R.S., B.H. Moody and D.B. Bradshaw. 1981. The forests of Newfoundland, their major pests and fire history. In J. Hudak and A.G. Raske (eds.). Review of the spruce budworm outbreak in Newfoundland - its control and forest management implications: Canadian Forestry Service submission to the Newfoundland and Labrador Royal Commission on Forest Protection and Management. pp 3-11. Nat. Res. Can., Can. For. Serv. - Atl. For. Ctr. Inf. Rep. N-X-205.

Van Wagner, C.E. 1965. Describing forest fires - old ways and new. For. Chron. 41(3): 301-305.

Van Wagner, C.E. 1971a. Two solitudes in forest fire research. Nat. Res. Can., Can. For. Serv. - PNFI, Chalk River, ON. Inf. Rep. PS-X29. $7 \mathrm{p}$.

Van Wagner, C.E. 1971b. Fire and red pine. Proc. Tenth Annual Tall Timbers Fire Ecology Conference, Fredericton, N.B., 1970, pp. 211-219.

Warren, G., P. Baines, J. Plamondon and D.G. Pitt. 2013. Effects of precommercial thinning on the forest value chain in northwestern New Brunsiwck: Part 3-Incidence of root and butt decay. For. Chron. 89(4): 464-473

Wein, R.W. and J.M. Moore. 1977. Fire history and rotations in the New Brunswick Acadian Forest. Can. J. For. Res. 7: 285-294.

Wein, R.W. and J.M. Moore. 1979. Fire history and recent fire rotation periods in the Nova Scotia Acadian Forest. Can. J. For. Res. 9: 166-178.

Weir, P. 2002. Snow avalanche: management in forested terrain. Research Branch, B.C. Ministry of Forests. Land Management Handbook 55.

Whitney, R.D., R.L. Fleming, K. Zhou and D.S. Mossa. 2002. Relationship of root rot to black spruce windfall and mortality following strip clear-cutting. Can. J. For. Res. 32(2): 283-294

Wilton, W.C. and C.H. Evans. 1974. Newfoundland forest fire history 1619-1960. Nat. Res. Can., Can. For. Serv. - Atl. For. Ctr. Inf. Rep. N-X-116. 